\title{
Transformative constitutionalism and the adjudication of constitutional rights in Africa
}

\author{
Eric Kibet \\ Senior Lecturer, Moi University, Kenya
}

\section{Charles Fombad}

Professor of Law and Head, Constitutional Law Unit, Institute for International and Comparative Law in Africa, University of Pretoria, South Africa

\section{Summary}

Transformative constitutionalism, popularised in the context of South Africa's transition from apartheid to constitutional democracy, arguably offers an antidote for failed constitutionalism and weak protection of fundamental rights and freedoms in emergent democracies in Africa. This article examines the idea of transformative constitutionalism and its implications for the adjudication of fundamental rights and freedoms. It recognises that past failures of constitutionalism in Africa, to a significant degree entailed state abuses of fundamental rights and the corresponding inability of the courts to uphold these rights. Using examples of adjudication of rights in the post-2010 period in Kenya and postapartheid era in South Africa, the article argues that, taken as a model for constitutionalism in Africa, transformative constitutionalism offers hope for increased protection of fundamental rights and freedoms. The article analyses the demands of transformative constitutionalism on the judicial adjudication of rights, and concludes that the concept demands more from judges than has traditionally been understood in the two legal systems.

Key words: transformative constitutionalism; rights adjudication; South African Constitution; Kenyan Constitution; human rights

* LLB (Nairobi) LLM (Boston College) LLD (Pretoria); erickibet@gmail.com

** Licence-en-Droit (Yaoundé) LLM PhD (London); cfombad@up.ac.za 


\section{Introduction}

In most parts of Africa the much-celebrated independence from colonialism was largely a failed project. ${ }^{1}$ In place of freedom, democracy and prosperity that many colonised people had hoped independence would bring, Africa's post-colonial era, especially in the early years of independence, was characterised by political instability, military coups and counter-coups, dictatorship, civil strife, corruption, massive violations of human rights and misery. 2 To put it figuratively, independence largely became a case of replacing $\mathrm{Mr}$ Jones with Napoleon in George Orwell's famed Animal farm classic. ${ }^{3}$ Similarly, the formation of the South African Republic in 1961, marking the end of allegiance to the British Crown, did not yield much fruit for the African majority. ${ }^{4}$ Rather, it meant a continuation and perfection of misery under the apartheid regime. ${ }^{5}$ Thus, South Africa's experience under the apartheid regime carries similarities with the colonial experience in the rest of Africa. These include racial segregation; discrimination; disenfranchisement and dispossession; political exclusion; and general socio-economic under-development. While South Africa's transition from apartheid may not be regarded as decolonisation in the same way as the rest of Africa was liberated from European colonial rule, it nonetheless was a process of liberation from a similar plight. Thus, the transition of South Africa from white domination following the multi-racial elections of 1994 may be equated to the liberation of the rest of Africa from colonial fetters in that governance and the power to shape the destiny of the country were now in the hands of a popularly-elected government comprising mainly of the black majority that had suffered marginalisation during apartheid.

The article argues that transformative constitutionalism is an ideal model to anchor constitutionalism and respect for human rights in Africa. Citing it as one of the fundamental pillars of post-apartheid constitutionalism in South Africa, it explores the concept and its implications for the adjudication of fundamental rights and freedoms. It recognises that past failures of constitutionalism in Africa to a

1 HK Prempeh 'Africa's "constitutionalism revival": False start or new dawn?' (2005) 3 International Journal of Constitutional Law 469.

$2 \mathrm{CM}$ Fombad 'Challenges to constitutionalism and constitutional rights in Africa and the enabling role of political parties: Lessons and perspectives from Southern Africa' (2007) 55 American Journal of Comparative Law 36-38. See also HWO Okoth-Ogendo 'The politics of constitutional change in Kenya since independence' (1972) 71 Africa Affairs 9.

3 G Orwell Animal Farm (1956) (a political satire in which animals carry out a coup to liberate themselves from the oppression of their human master, Mr Jones; pigs become the ruling elite in the society of 'free animals', but soon the new regime becomes corrupt and institutes a system that has all the oppressive features of the previous one).

4 J Dugard 'A bill of rights for South Africa?' (1990) 23 Cornell International Law Journal 442-443.

5 As above. 
significant degree entailed state abuses of fundamental rights and the corresponding inability of the courts to uphold these rights. Using examples of adjudication of constitutional rights in the post-2010 period in Kenya and post-apartheid era in South Africa, the article contends that transformative constitutionalism as a model for constitutionalism in Africa offers hope for the better protection of fundamental rights and freedoms. The article analyses the demands of transformative constitutionalism on the judicial adjudication of rights, and concludes that the concept demands more from judges than has traditionally been understood in the two legal systems. The next section gives a brief overview of the history of constitutionalism and the protection of fundamental rights and freedoms in post-colonial Africa.

\section{History of constitutionalism and the protection of rights in Africa}

The quest to strike a balance between anarchy, on the one hand, and tyranny, on the other, is a key preoccupation of constitutional law and the core of constitutionalism. 6 The primary function of constitutions is to strike this balance by establishing power maps for the exercise of public power in a fashion that ensures that the government is neither too weak nor despotic. ${ }^{7}$ Thus, constitutions create state institutions, allocate to them powers and, importantly, define the limits of their powers. $^{8}$ In this sense, constitutionalism is the notion of government limited by law. ${ }^{9}$ It posits that it is possible and, indeed, desirable, that government should be limited by law, the constitution sitting at the top in the hierarchy of law. ${ }^{10}$ Broadly speaking, constitutionalism encompasses a number of elements such as the protection of fundamental rights and freedoms; the concept of separation of powers; independence of the judiciary; review of laws for constitutionality; and regulation of amendments to the constitution. ${ }^{11}$ Fombad, however, cautions that these elements do not automatically guarantee constitutionalism. ${ }^{12}$ A mechanism through which citizens can seek legal redress in courts for constitutional violations and to enforce constitutional obligations is necessary to ensure constitutional justice. ${ }^{13}$ In this regard, Okoth-Ogendo adds that constitutionalism also entails a culture or commitment by the political elite to respect

AW Bradley \& KD Ewing Constitutional and administrative law (2010).

B Nwabueze Constitutional democracy in Africa (2003) 36-45.

Nwabueze (n 7 above).

Bradley \& Ewing (n 6 above).

As above.

Fombad (n 2 above) 7-8.

Fombad (n 2 above) 10-14.

13 Fombad (n 2 above). Arts 258(1) \& (2), 22(1) \& (2) and 70(1) of the Constitution of Kenya 2010 have severely reduced rules of locus standi and ripeness, making it easy to institute constitutional and human rights cases. 
and abide by constitutional limits, since it is possible, in his words, to have 'constitutions without constitutionalism' ${ }^{14}$

The elusiveness of constitutionalism in post-colonial Africa has attracted the attention of many scholars in Africa. Okoth-Ogendo, for instance, decried Africa's post-colonial situation as one of 'constitutions without constitutionalism'. ${ }^{15}$ Prempeh notes that soon after independence, many constitutions ended up in the dustbins of despots who had little regard for constitutionalism and the rule of law. ${ }^{16}$ He describes the early years of independence under the first generation of African leaders as one characterised by the reign of 'founding fathers' who enjoyed 'founders' rights' and, therefore, were above challenge or accountability to citizens and indeed state institutions. ${ }^{17}$ They also either inspired or commanded homage from the citizens and the question of being subjects of the law and the Constitution in the same way as ordinary people was unimaginable. ${ }^{18}$ The description of Presidents Jomo Kenyatta and Daniel arap Moi of Kenya as mzee, ${ }^{19}$ baba wa taifa, ${ }^{20}$ mtukufu, ${ }^{21}$ 'father of the nation' illustrate this point. These two presidents had become so idolised that there was a common belief among some of their loyalists that they were constitutionally above the law. ${ }^{22}$ The same could be said of Ghana's Kwame Nkurumah, Zimbabwe's Robert Mugabe, Malawi's Kamuzu Banda, Milton Obote of Uganda, and Guinea's Sekou Toure, among others. Although these 'larger-than-life' individuals were seen as liberators from colonial rule, they presided over the subversion of democracy, the rule of law and constitutional order as part of a scheme of consolidation of power. ${ }^{23}$ During their reign, constitutions were discarded, ignored or amended to concentrate power in the executive and weaken other institutions such as legislatures and the

14 HWO Okoth-Ogendo 'Constitutions without constitutionalism: An African political paradox' in D Greenberg et al (eds) Constitutionalism and democracy: Transitions in the contemporary world (1993) 65.

15 As above.

16 Prempeh (n 1 above) 473-475.

17 Prempeh 481.

18 As above.

19 Meaning the 'revered elder'.

20 Meaning 'father of the nation'.

21 Meaning 'most excellent one'.

22 See eg official parliamentary Hansard record, 4 December 1991, recording the assistant Minister for Manpower, Development and Employment, Mr Lugonzo, saying that the President is 'constitutionally above the law'. In his inaugural speech, the newly-appointed Attorney-General, Amos Wako, in 1991 is also on record to have told parliament that the idea of the rule of law in Kenya was to the effect that 'nobody, except the President, is above the law'. See A Shiundu 'After 20 years, Wako serves last days as Kenya's AG' The Daily Nation, 14 August 2011 http://www.nation.co.ke/News/politics/After+20+years+Wako+serves+last+days+ as+Kenyas+AG+/-/1064/1218988/-/1410vbd/-/index.html (accessed 7 August 2016).

23 Prempeh (n 1 above). 
courts. ${ }^{24}$ The result was a lack of accountability that created a perfect environment for corruption, political repression and human rights abuses. $^{25}$ For this reason, Prempeh blames these generations of African leaders and their regimes for failed constitutionalism and the misery that followed.

While some independence constitutions, such as that of Kenya, created frameworks for multiparty democracy and the protection of human rights, ${ }^{26}$ the post-colonial epoch quickly changed and took the shape of one-party rule, personal presidential dictatorships or military juntas. ${ }^{27}$ Many post-colonial regimes perfected the repression of the colonial masters and failed to institute meaningful social, political and economic change. ${ }^{28}$ For Kenya, in particular, the first four decades of independence were dominated by the independence party and characterised by personal presidential rule that was completely intolerant of political competition. ${ }^{29}$ The same could be said of Ghana, Zimbabwe, Malawi, Uganda, Guinea, and Nigeria under military rule.

The evils of the apartheid regime in South Africa are well documented. Systemic racial discrimination, marginalisation and dispossession was the official policy backed by law. The state deployed violence against dissidents with tragic consequences as many were killed, maimed, tortured, detained without trial, or imprisoned under apartheid laws. ${ }^{30}$ The next section highlights how courts, at the height of dictatorship and political repression, largely failed to defend constitutionalism and the rule of law.

\section{Courts in the context of failed constitutionalism and human rights abuses in Africa}

In constitutional arrangements generally, courts of law have the task of upholding the rule of law, constitutionalism and fundamental rights. ${ }^{31}$ In functioning democracies, the ideal situation is that the state and all its instrumentalities ought to commit to, respect and uphold these values. The reality, however, shows that more often than not the state and its agents, indeed, are the violators as these values

24 As above. See also SD Mueller 'The political economy of Kenya's crisis' (2008) 2 Journal of Eastern African Studies 185; doi 10.1080/17531050802058302.

25 Fombad (n 2 above).

26 Prempeh (n 1 above).

27 As above.

28 As above.

29 MW Mutua Kenya's quest for democracy: Taming Leviathan (2008).

30 See eg The Report of the Truth and Reconciliation Commission (Vol 1-5) http:// www.justice.gov.za/trc/report/ (accessed 15 November 2016).

31 Nwabueze (n 7 above) 19-30. 
serve as limits and inconveniences in the course of the exercise of power. ${ }^{32}$ In light of this, a question arises as to how the courts lived up to their mandate of upholding rights and the rule of law, especially in the early years of Africa's independence. How did the courts handle their constitutional responsibilities in the face of despotic and repressive regimes?

The story of the responses of the courts to political repression and abuses of human rights by the state in post-colonial Africa, of course, cannot be over-generalised. However, there is a clear pattern that courts were generally either impotent or complicit. ${ }^{33}$ A few illustrations support this assertion. During the one-party rule, in Kenya, for example, the judiciary generally was unable to protect and enforce human rights against a despotic executive. ${ }^{34}$ The judiciary constantly avoided making decisions that would upset the executive, especially the President. ${ }^{35}$ In Matiba $v$ Moi, ${ }^{36}$ an election petition filed against the incumbent, President Daniel arap Moi, by a presidential candidate in the 1992 elections was dismissed because the petitioner had not signed the election petition in person as required by the election law. The Electoral Commission had announced Moi as the winner of the election. Matiba, who was a presidential candidate, disputed the election results and filed a petition before the High Court. However, he could not personally sign the petition because he had suffered a stroke which impaired him physically, making him unable to write. Instead, his wife signed the petition on his behalf under a power of attorney granted to her by the petitioner. On the basis of this technicality, the Court refused to entertain the petition arguing that the law was clear that the petitioner must sign in person. In so holding, the Court ignored the real issues and denied the petitioner justice on the basis of a technicality.

In 1997, the second elections since the return of multipartyism in Kenya in 1992 were held. Mwai Kibaki, who emerged second, disputed the results and filed a petition against the incumbent, President Moi, who had been declared the winner. ${ }^{37}$ The High Court again dismissed the suit on the basis of a technicality. Election laws required that an election petition must be served in person upon the respondent. ${ }^{38}$ The petitioner's lawyers had not served President Moi personally. The reality was that attempts to serve the President personally were frustrated by his security detail. Although these

32 Nwabueze (n 7 above).

33 Human Rights Watch World Report 1989 https://www.hrw.org/reports/1989/ WR89/Kenya.htm (accessed 10 November 2012).

34 MW Mutua 'Justice under siege: The rule of law and judicial subservience in Kenya' (2001) 23 Human Rights Quarterly 97.

35 JT Gathii 'The dream of judicial security of tenure and the reality of executive involvement in Kenya's judicial process' (1994) Thoughts on Democracy Series (Issue II) 10 .

36 Election Petition 27 of 1993.

37 Kibaki v Moi Election Petition 1 of 1998.

38 Ch 7 sec 20(1)(b) National Assembly and Presidential Elections Act. 
frustrations were brought to the attention of the Court, it still dismissed the petition, thereby denying the petitioner justice. On appeal, the Court of Appeal upheld the decision of the High Court. ${ }^{39}$

Gibson Kamau Kuria $v$ Attorney-General ${ }^{40}$ is another case that illustrates the courts' connivance or helplessness in enforcing fundamental rights and the rule of law during the one-party era in Kenya. In this case, Gibson Kamau Kuria had been awarded the Robert F Kennedy Human Rights Award from the Robert F Kennedy Center for Justice and Human Rights in the United States for defending human rights in Kenya. He received an invitation to travel to the United States to receive the award. The government of Kenya was unhappy with this award as it considered Kuria an opponent of the regime. It responded by confiscating his passport to prevent him from travelling. Kuria sued the state to compel it to return his passport so that he could travel to receive the award. The High Court dismissed the case on the pretext that, although the right to freedom of movement was guaranteed, the Court could not enforce it since the Chief Justice 'had not made rules' to guide the litigation process. ${ }^{41}$ In so holding, the Court sacrificed the protection of fundamental rights and freedoms on the altar of technicalities. It was curious that the Chief Justice, who had failed to make rules to guide constitutional litigation, in fact was on the same bench that refused to entertain the case under the guise of a lack of rules. ${ }^{42}$ It is also worth noting that before this decision, constitutional litigation had been going on for years and this technical situation had not hindered courts from enforcing rights in the past. ${ }^{43}$ This suggests that the Court only resorted to the technicality in order to conveniently avoid upsetting the executive, which was determined to frustrate the petitioner.

The same situation is generally reflected in most of Africa especially before the multiparty wave that began in the 1990s. ${ }^{44}$ In South Africa, the capacity of the courts to enforce and protect human rights was severely hampered by legal and constitutional designs aimed at supporting apartheid. ${ }^{45}$ First, the doctrine of parliamentary supremacy entrenched in pre-1993 Constitutions ensured the

39 Nairobi Civil Appeal 172 of 1999.

40 High Court Miscellaneous Application 279 of 1985 (unreported).

41 Sec $84(6)$ of the repealed Constitution of Kenya empowered the chief justice to make rules to guide the enforcement of fundamental rights and freedoms. It is surprising that no rules were made subsequently to 2001. Therefore, some courts resisted to enforce the Bill of Rights for technical reasons, while others took the view that the absence of rules of procedure could not defeat substantive rights. See, generally, M Thiankolu 'Landmarks from El Mann to the Saitoti ruling: Searching a philosophy of constitutional interpretation in Kenya' (2007) Kenya Law Journal http://www.kenyalawreports.or.ke/Downloads_Other/Landmarks_ from_El_Mann_to_the_Saitoti_Ruling.pdf (accessed 20 June 2015).

42 Gathii (n 35 above).

43 As above.

44 CM Fombad 'Constitutional reforms and constitutionalism in Africa: Reflection on some challenges and future prospects' (2011) 59 Buffalo Law Review 1007. 
subordination of the judiciary to a legislature that did not represent the interests of the black majority. ${ }^{46}$ Amendments to the 1910 Constitution, for example, specifically denied courts the power to review the constitutionality of laws enacted by parliament. ${ }^{47}$ The implication of this rule was that whatever parliament enacted, however outrageous, could not be challenged. This subordination, which was retained in subsequent Constitutions of 1961 and 1983, entrenched apartheid laws that provided for gross human rights violations such as racial discrimination, detention without trial, suppression of freedom of expression, and the denial of orders of habeas corpus. 48

Second, the pre-1993 Constitutions did not contain bills of rights. This fact, coupled with the official constitutional subordination of the judiciary, meant that there was no basis upon which the courts could enforce fundamental rights and freedoms. ${ }^{49}$ Third, at the time, staffed by white judges trained by a legal education system designed to support apartheid, courts could not do much to advance the agenda of protecting fundamental rights and freedoms, especially those of the marginalised African majority. ${ }^{50}$ Klare describes this problem as 'legal culture' that limited the way in which lawyers think and determined their sensibilities and responses to issues. ${ }^{51}$ In other words, the despotism and abuses of human rights in the pre-1993 period were sustained, at least in part, by a legal culture fashioned to support the apartheid policy. More generally, where were the courts amidst widespread human rights abuses by rogue regimes in post-colonial Africa? Examples from Kenya cited above, and from Nigeria under the various military regimes, show that courts for the most part chose to avoid controversy by resorting to technicalities of the law and rigid positivism or formalism that emptied legal human rights protection of their substance. ${ }^{52}$

Nevertheless, it is important to acknowledge the fact that during the early years of Africa's independence in countries presided over by civilian or military dictators, the courts operated under extremely difficult political circumstances. Judicial courage sometimes had tragic or even fatal consequences as some regimes were prepared to go to

\footnotetext{
46 As above.

47 Under the constitutional design that existed, parliament was sovereign. Whatever parliament enacted could not be invalidated by the courts.

48 Dugard (n 4 above) 443-444. Cases such as Harries \& Others $v$ Minister of Interior \& Another 1952 (2) SA 428 (A); Minister of the Interior \& Another $v$ Harries \& Others 1952 (4) SA 769 (A); and Collins $v$ Minister of the Interior \& Another 1957 (1) SA 552 (A) are good examples.

49 Dugard (n 4 above).

50 T Madala 'Rule under apartheid and the fledgling democracy in post-apartheid South Africa: The role of the judiciary' (2000-2001) 26 North Carolina Journal of International Law and Commercial Regulation 749-751.

51 K Klare 'Legal culture and transformative constitutionalism' (1998) 14 South African Journal on Human Rights 146150.

52 B Ogochukwu 'Adjudicating human rights in transitional contexts: A Nigerian case study, 1999-2009' unpublished PhD thesis, Osgood Hall Law School, 2014.
} 
whatever lengths to rule while ignoring constitutionalism and the rule of law. ${ }^{53}$ As a result, some judges simply avoided issuing orders with which they believed the political elite was not prepared to comply. As was common during Nigeria's notorious military regimes, many judges avoided issuing such orders on the rationale that doing so would open the courts to embarrassment and further erode the already shaky judicial authority. ${ }^{54}$ In spite of these circumstances, Prempeh and other African scholars assert that the judiciary cannot escape blame for the failure of constitutionalism in post-colonial Africa. ${ }^{55}$ Although the executive was determined to entrench its rule at all costs, including ignoring constitutionalism and the rule of law, there are examples of many squandered opportunities where courts simply failed to stand up to defend these values, or even connived in their subversion.

The next part discusses the idea of transformative constitutionalism and assesses whether the adoption of the concept could cure some of the problems in constitutional adjudication highlighted in this section.

\section{Transformative constitutionalism: An antidote for past failures?}

Although South Africa's transition in 1994 entailed the assumption of power by an African majority government, the post-apartheid South Africa has generally escaped the constitutional failures and turmoil that befell most of Africa following the departure of colonial powers. Since the transition, the country has strived to uphold democracy, constitutionalism and the rule of law despite numerous challenges that could predispose it to a similar fate. What followed the end of apartheid were concerted legal and political processes of correcting the wrongs of the past and establishing an egalitarian constitutional order, which distinguished South Africa as a model of socio-political change through law. From the implementation of the 1993 interim Constitution to the enactment and operationalisation of the 1996 final Constitution, the courts have been pivotal as guardians of the transformation, handing down landmark decisions that affirm a resolute commitment to human rights and the new order generally. ${ }^{56}$ The question that then arises is: What sets South Africa apart from other African states? What spares the country from the turmoil that followed the departure of European colonial powers in most of Africa?

There are many possible answers to this question. First, although there were deep political divisions in South Africa that could have resulted in turmoil as in many other African countries, the ravages of

\footnotetext{
53 As above.

54 As above. For Kenya in particular, see Gathii (n 35 above).

55 Ogochukwu (n 52 above).

56 Fombad (n 44 above) 1069.
} 
apartheid and the fact that the white minority group that had been politically dominant were not departing, compelled various factions to work together for change through peaceful means. Second, South Africa's transition occurred at a time when a wave of democratisation was sweeping across Africa following the collapse of the Soviet Union. The appeal of the values of democracy, the rule of law and human rights, drummed up by the West, took centre stage now that the Cold War had ended or weakened. ${ }^{57}$ This influence was readily taken up and reflected in South Africa's constitutional change and subsequent practice. ${ }^{58}$ Third, and perhaps most importantly, was the recognition of the inadequacies of the Western liberal constitutional model to prevailing socio-political realities in South Africa. Constitutionalism, simply understood as the idea of limited government, was transplanted into African constitutional thought mainly though the agency of European colonial powers who acted as patrons of the decolonisation process and handed down to the newly-independent African states constitutions modelled after European constitutions. ${ }^{59}$ However, these models, fashioned after Western liberal ideology, failed to meet the peculiar needs of African situations characterised by widespread poverty, underdevelopment, wide ethnic and cultural diversity as well as African communitarian orientation. ${ }^{60}$

Klug argues that South Africa's transformation took place against a declining dominance of liberalism and a corresponding rise in social democracy or liberal egalitarianism. ${ }^{61}$ Liberal ideology, premised mainly on formal autonomy and abstract equality, had been on the decline, ${ }^{62}$ and had faced criticism for failing to adequately meet the challenges of non-Western societies in Africa and elsewhere. These critiques of Western classical liberalism and responses through social democracy or liberal egalitarianism constitute one of the external influences on South Africa's post-apartheid era. ${ }^{63}$ As an internal influence, political sentiments fomented by historical marginalisation, systemic discrimination, disenfranchisement and human rights abuses,

57 M Mutua 'The transformation of Africa: A critique of the rights discourse' in FG Isa \& $\mathrm{K}$ de Feyter (eds) Human rights and diversity: International human rights law in a global context (2009) 899, https://ssrn.com/abstract=1526734 (accessed 5 October 2017).

$58 \mathrm{H}$ Klug Constituting democracy: Law, globalism and South Africa's political reconstruction (2000).

59 Prempeh (n 1 above).

60 N Bohler-Muller 'Western liberal legalism and its discontents: A perspective from post-apartheid South Africa' (2007) 3 Social-Legal Review 1.

61 Klug (n 58 above).

62 As above. See also T Allen 'Liberalism, social democracy and the value of property under the European Convention on Human Rights' (2010) 59 International and Comparative Law Quarterly 1055. The trend here is one of counter-balancing classical liberal ideals with social democratic ideals, not death of classical liberalism ideology. The labour movement and labour law as a transitional project have greatly contributed to the rise in social democratic ideals in Europe and the rest of the world.

Klug (n 58 above). 
provided the impetus for an egalitarian order. ${ }^{64}$ Thus, South Africa's transformation process fashioned a social democratic or liberal egalitarian system premised on the traditional concept of constitutionalism in the liberal sense, but going beyond it to include pragmatic designs to address prevailing social and political realities. ${ }^{65}$ This is what Klare has described as 'transformative constitutionalism', and which is discussed in detail below.

The traditional notion of constitutionalism is inadequate in meeting peculiar needs of transitional societies emerging from traumatic pasts characterised by war, deep divisions or political repression. In such societies, constitutions and law generally have to do more, 66 including addressing past injustices and crises as well as inspiring hope for a better future. ${ }^{67}$ Inevitably, the law and politics divide faces the greatest challenge as the law is engaged in mediating political change. ${ }^{68}$ South Africa's interim Constitution of 1993 and the final 1996 Constitution provide a good illustration in this regard. They devised delicately-balanced mechanisms to end an immoral and oppressive legal and political regime and usher in a more inspiring future. ${ }^{69}$ The goal was to end apartheid and institute a democratic regime founded on freedom, multiculturalism, equality, equity, respect for human dignity and human rights. ${ }^{70}$ To this list, Klare adds the protection of socio-economic rights, the imposition of positive duties on the state to ensure the enjoyment of human rights, and the horizontal applicability of the Constitution. ${ }^{71}$ This necessitated a Constitution designed not only to limit government powers in the traditional sense, but also to institute social and political transformation as a means of lending legitimacy to the new constitutional and political order. ${ }^{72} \mathrm{~A}$ constitutional and political change that would not help to emancipate previously-oppressed groups and create an egalitarian society in which the interests of all are protected would suffer a serious legitimacy problem, hence the

64 As above.

$65 \mathrm{H}$ Klug 'Towards a sociology of constitutional transformation: Understanding South Africa's post-apartheid constitutional order' (2016) University of Wisconsin Legal Studies Research Paper 1373.

$66 \mathrm{R}$ Teitel 'Transitional jurisprudence: The role of law in political transformation' (1997) 106 Yale Law Journal 2014 (arguing that law in transitional situations plays the role of facilitating both change and stability).

67 Klug (n 58 above).

68 Teitel (n 66 above).

69 Klug (n 58 above). See also A Chaskalson 'From wickedness to equality: The moral transformation of South African law' (2003) 1 International Journal of Constitutional Law 590.

70 D Moseneke 'A journey from the heart of apartheid darkness towards a just society: Salient features of the budding constitutionalism and jurisprudence of South Africa' (2012) 101 Georgetown Law Journal 749.

71 Klare (n 51 above) 153.

72 Klare (n 51 above). 
need for a transformative constitution and the idea of transformative constitutionalism. ${ }^{73}$

The colonial system pursued by the British administration in Kenya was very similar to South Africa's apartheid regime to the extent that it was based on ideas of white racial supremacy and exploitation. ${ }^{74}$ The law was skewed to serve the interests of minority colonial settlers and the colonial administration while subjugating and alienating the black majority. ${ }^{75}$ Under the system, state authority was unchallengeable and unaccountable ${ }^{76}$ in the same way that Mureinik described apartheid as a system operating on a 'culture of authority' in which the state did not need to justify its actions. ${ }^{77}$ Although a liberal democratic constitution was adopted to usher in Kenya's independence, the colonial system of administration, with its laws, attitudes and traditions, was bequeathed almost intact upon the African political elite. Among the top priorities of the political elite after independence was to consolidate political power. Thus, soon after independence, the Constitution was amended in fundamental ways such that by 1982, Kenya had become a highly-centralised unitary de jure one-party state with an 'imperial presidency', and with institutions too weak to safeguard human rights, the rule of law and constitutionalism. ${ }^{78}$ As a result, the first three decades of Kenya's independence were characterised by despotism, a refusal by the state to institute land reforms, and widespread human rights abuses. ${ }^{79}$ It is against this background that the 2010 Constitution of Kenya was enacted to institute social and political transformation in the country. This transformation entails a reconfiguration of the governance structures and the equilibrium of power among state institutions; the democratisation of governance; changing the normative

73 Klare (n 51 above) 150. (Mureinik described the Interim Constitution as a 'bridge' from authority to a culture of justification: $E$ Mureinik 'A bridge to where Introducing the interim Bill of Rights' (1994) 10 South African Journal on Human Rights 32.

74 E Huxley White man's country: Lord Delamere and the making of Kenya (1969).

75 MK Mbondenyi et al Human rights and democratic governance in Kenya: A post2007 appraisal (2007).

76 CM Ngugi 'Free expression and authority in contest: The evolution of freedom of expression in Kenya' unpublished PhD thesis, Emory University, 2007.

77 Mureinik (n 73 above) 31.

78 Mureinik ( $\mathrm{n} 73$ above). See also MW Mutua 'Human rights and state despotism in Kenya: Institutional problems' (1994) 41 Africa Today 50 (illustrating how the Kenyan state under Jomo Kenyatta and Daniel Moi presided over a despotic government that carried out widespread human rights abuses). See also Mueller (n 24 above) (arguing that the political crisis in Kenya in the aftermath of the disputed presidential elections of 2007 was a consequence of a deliberate scheme in the post-independence period to weaken state institutions to appoint where they could not be trusted to act as credible mediators). It should be recalled that in 1988, the security of tenure of judges was removed. Although it was later restored, the judiciary remained largely weak in relation to the executive arm of government. See eg Mutua (n 34 above) 96 and Gathii (n 30 above). See also Mueller (n 24 above). The term 'imperial presidency' is attributed to OkothOgendo (n 1 above). 
arrangements; culture, attitudes and practices that surround politics and the exercise of public power; as well as a robust protection of civil and political rights, socio-economic rights, solidarity rights and gender equality rights so as to shift state-citizen relationship in an egalitarian direction.

Through the 2010 Constitution, Kenya adopted a transformative Constitution modelled after that of South Africa and tailor-made to address situations peculiar to the country. The Constitution seeks to do more than secure constitutionalism in the traditional sense. Its vision is to redress social and political crises in the country; both those that are a legacy of colonialism and those that began in the postcolonial era. The Supreme Court of Kenya recognised this transformative character in Speaker of the Senate \& Another $v$ AttorneyGeneral \& Another \& 3 Others, ${ }^{80}$ in which it held: ${ }^{81}$

Kenya's Constitution of 2010 is a transformative charter. Unlike the conventional 'liberal' Constitutions of the earlier decades which essentially sought the control and legitimisation of public power, the avowed goal of today's Constitution is to institute social change and reform, through values such as social justice, equality, devolution, human rights, rule of law, freedom and democracy ...

In a subsequent decision in Communications Commission of Kenya \& 5 Others $v$ Royal Media Services Limited \& 5 Others, ${ }^{82}$ the Supreme Court of Kenya, citing Klare, observed that in enacting the 2010 Constitution, Kenya had entered the league of India, South Africa, Colombia and other countries that have embraced transformative constitutionalism as a model for social and political change. ${ }^{83}$

What then is transformative constitutionalism and what are its essential elements? The idea has received a lot of scholarly attention since the end of apartheid in South Africa and its transition to a constitutional democracy. Writing in the context of South Africa's 1996 Constitution, Klare defines 'transformative constitutionalism' as

a long-term project of constitutional enactment, interpretation, and enforcement committed ... in a historical context of conducive political developments) to transforming a country's political and social institutions and power relationships in a democratic, participatory, and egalitarian direction. ${ }^{84}$

Other scholars have also commented extensively on transformative constitutionalism in the context of South Africa. The late Chief Justice of the Constitutional Court of South Africa, Pius Langa, for instance,

80 [2013] eKLR.

81 Para 51 (our emphasis).

82 [2014] eKLR (Petition 14 as consolidated with Petitions 14A, 14B and 14C of 2014).

83 Royal Media Services (n 82 above) para 377.

84 Klare (n 51 above) 150. 
acknowledged the difficulty of defining the concept in juridical terms, noting that social and political change is its primary goal. ${ }^{85}$

Although the meaning and scope of transformative constitutionalism may be disputed, a number of its elements may be deduced. In contrast to classical liberalism which assumes formal equality, its focus is on substantive equality and substantive justice. This entails a deliberate effort to empower previously-excluded segments of society through devices such as the protection of socioeconomic rights, and others aimed at the attainment of social justice. This inevitably requires a broader view of justice beyond the narrow 'negative rights' conception since the realisation of substantive justice requires proactivity by the state. This necessarily requires less emphasis on technicalities and procedure so as to maximise the realisation of substantive rights. In a legal context, this entails methods of legal reasoning that transcend formalism or positivism to ensure that rights are indeed enjoyed. ${ }^{86}$ In this regard, Klare suggests a 'post-liberal' reading of the Constitution since the Constitution is itself post-liberal, requiring more than the minimum guarantees of the liberal conception. ${ }^{87}$ In addition, this aspect requires a change in lawyers' understanding of the law and its role in society and politics. This is what Klare calls 'legal culture', which he defines to mean lawyers' 'professional sensibilities, habits of mind, and intellectual reflexes' ${ }^{88}$ Since transformative constitutionalism places a lot of faith in the law as an instrument for social and political change, it follows that lawyers, including judges (as well as legislators and law enforcers), must view the law as such and be prepared to conceptualise and deploy it to achieve the envisaged transformation.

Transformative constitutionalism, however, has received a fair amount of criticism. For example, it has been criticised for obscuring the law-politics divide. ${ }^{89}$ The objective of attaining social or substantive justice through law inevitably compels courts to engage in policy decision making or make orders that have significant budgetary implications such as in the enforcement of socio-economic rights. This inevitably creates points of conflict with the political arms of government that largely retain the power over policy and government expenditure. ${ }^{90}$ This is perhaps the most controversial element of

85 P Langa 'Transformative constitutionalism' (2006) 17 Stellenbosch Law Review 351.

86 T Roux 'Transformative constitutionalism and the best interpretation of the South African Constitution: Distinction without a difference?' (2009) 2 Stellenbosch Law Review 260.

87 Klare (n 51 above) 150-151. Roux (n 86 above) sees the interpretative approach advocated by Klare as the critical legal studies approach, and adds that the approach advocated by Dworkin in his theory of interpretation is another plausible approach.

88 Klare (n 51 above) 166-167.

89 Roux (n 86 above).

90 An order for the enforcement of socio-economic rights such as food, healthcare and housing, requires the deployment of financial resources and effort, for example. 
transformative constitutionalism as it necessarily engages the judiciary in the murky waters of politics and policy decision making. ${ }^{91}$ It is more controversial because the contours of judicial activism that sometimes goes with transformative constitutionalism are undefined or amorphous. This facet of transformative constitutionalism could mean judicial pragmatism in bringing about socio-political change. It could also sound a death knell for the legitimacy of the judiciary since it may bring it into direct collision with political players who feel more entitled to drive the political agenda. In addition, transformative constitutionalism has been criticised as being an insufficient cure for widespread poverty and inequality that continue to ravage postcolonial Africa. ${ }^{92}$ Despite the celebration of transformative constitutionalism in scholarly commentary, landmark decisions of the courts and development milestones reached in South Africa since the end of apartheid, deep poverty and inequality continue to be a big challenge. Sibanda in his criticism argues that this failure is partly because, while the concept is touted as 'post-liberal', it sits comfortably within liberal discourses and fails to place poverty eradication at the centre of constitutional discourses. ${ }^{93}$

Despite these criticisms, it is clear that transformative constitutionalism offers hope for better prospects of constitutionalism and protection of fundamental rights in Africa. What becomes clear is that transformative constitutionalism takes a more pragmatic approach towards the realisation of constitutionalism and fundamental rights and freedoms. This is essential especially in emergent democracies in the global south where the culture of human rights and constitutionalism is either nascent or fragile. There is little doubt that the present South Africa is better off than in the apartheid era as far as the protection of human rights, the rule of law and constitutionalism are concerned. ${ }^{94}$ The landmark decisions of the South African Constitutional Court in National Coalition for Gay and Lesbian Equality \& Another $v$ Minister of Justice \& Others ${ }^{95}$ (striking down laws criminalising sex between consenting males); Minister of Home Affairs \& Another $v$ Fourie \& Another ${ }^{96}$ (validating same-sex marriages); Du Toit \& Another $v$ Minister of Welfare and Population

91 K van Marle 'The spectacle of post-apartheid constitutionalism' (2007) 16 Griffith Law Review 418.

92 S Sibanda 'Not purpose-made! Transformative constitutionalism, postindependence constitutionalism and the struggle to eradicate poverty' (2011) 22 Stellenbosch Law Review 482.

93 As above.

94 F Michelman 'Liberal constitutionalism, property rights, and the assault on poverty' (2011) 22 Stellenbosch Law Review 706 gives a more comprehensive rebuttal of Sibanda's criticism. Also see Sibanda's reply to Michelman in S Sibanda 'Not quite a rejoinder: Some thoughts and reflections on Michelman's liberal constitutionalism, property rights, and the assault on poverty' (2013) 24 Stellenbosch Law Review 329.

951999 (1) SA 6 (CC).

96 [2005] ZACC 19. 
Development \& Others ${ }^{97}$ (affirming the rights of a lesbian couple to jointly adopt a child); S v Makwanyane \& Another ${ }^{98}$ (striking down the death penalty); Government of the Republic of South Africa \& Others $v$ Grootboom \& Others ${ }^{99}$ (affirming the right to adequate housing for the most vulnerable in the society); and Economic Freedom Fighters $v$ Speaker of the National Assembly \& Others; Democratic Alliance $v$ Speaker of the National Assembly \& Others ${ }^{100}$ (ordering President Jacob Zuma to refund public funds used to improve his private Nkandla home in violation of the Constitution) and others, are outstanding, and illustrate this point.

Similarly, the prospects of protection of human rights and respect for constitutionalism and the rule of law in Kenya are better than in any other time in the country's history. Decisions such as Eric Gitari $v$ Non-Governmental Organisations Co-ordination Board \& 4 Others (affirming freedom from discrimination on grounds of sex including sexual orientation); ${ }^{101}$ Kituo Cha Sheria $v$ Independent Electoral and Boundaries Commission \& 2 Others (affirming prisoners' rights to vote) $i^{102}$ Coalition for Reform and Democracy (CORD), Kenya National Commission on Human Rights and Samuel Njuguna $\mathrm{Ng}^{\prime} \mathrm{ang}^{\prime}$ a $v$ Republic of Kenya \& Another (invalidating various security laws seeking to restrict freedom of expression); ${ }^{103}$ and Trusted Society of Human Rights Alliance $v$ Attorney-General \& Others (invalidating various decisions of the President and parliament for failing to comply with the Constitution) ${ }^{104}$ are unprecedented, and best illustrate this point. Although the transformative jurisprudence from the courts in the two jurisdictions are at different levels of development, it is clear that there is a shift in both towards a value-based approach to the interpretation and enforcement of rights, and the Constitution generally. This, obviously, signifies the courts' stronger commitment to uphold the rule of law, constitutionalism and the enjoyment of rights. ${ }^{105}$ If the momentum set by the courts in these two jurisdictions is sustained and diffused elsewhere in Africa, the outcome would be what Prempeh has described as 'rights-friendly' jurisprudence. ${ }^{106}$

\footnotetext{
$972003(2)$ SA $198(C C)$.

$98($ CCT3/94) [1995] ZACC 3.

$99($ CCT11/00) [2000] ZACC 19.

100 [2016] ZACC 11.

101 [2015] eKLR.

102 [2013] eKLR.

103 [2015] eKLR.

104 [2012] eKLR (HCK). This decision was later overturned on appeal, but the appointments made by the President and approved by the National Assembly were ineffectual for months while the appeal was pending. See also Institute of Social Accountability \& Another v National Assembly \& 4 Others [2015] eKLR in which the Court invalidated a popular law passed by the National Assembly and directed it to remedy its faults.

105 Mureinik (n 73 above) 32.

106 Prempeh (n 1 above) 504.
} 
It has become clear that transformative constitutionalism relies on the law and courts as the final arbiters of the meaning of the law for the success of its objectives. The question that arises concerns the demands of transformative constitutionalism on judges and the judicial process. The next section answers this question by exploring transformative constitutionalism in the adjudicative context.

\section{Transformative constitutionalism in the adjudicative context}

Since World War II, many democracies around the world have embraced 'judicialism', the notion that courts bear the ultimate power to declare the meaning of the law such that all other state organs must submit to their determinations. ${ }^{107}$ Since the 1950 s judicial power has been on the rise, to a point where the courts often get involved in matters that can be regarded as political or having significant political implications, such as nullifying legislation and other political outcomes, and reviewing policy decisions or even getting involved in policy making. ${ }^{108}$ Many democracies now have apex constitutional courts with the power to proclaim the meaning and demands of the constitution and fundamental rights in a fashion that binds and constrains the political arms of government, and heightens the age-old countermajoritarian difficulty. ${ }^{109}$ Stone Sweet has described this phenomenon as 'judicialisation'. ${ }^{110}$ Klug, for his part, sees this feature as an essential element of modern 'global constitutionalism'. ${ }^{111}$ On Kenya in particular, Ojwang argues that judicialism and (transformative) constitutionalism are the two defining ideologies of the Kenyan Constitution, and notes that the judiciary is the greatest beneficiary of the changing political philosophy ordained under the 2010 Constitution. ${ }^{112}$ This is because contrary to its previous weak form, the judiciary under the 2010 Constitution enjoys immense powers as the final arbiter of legal and constitutional matters, including some that are political in nature, thanks to the ideology of judicialism. ${ }^{113}$

What does transformative constitutionalism require of judges as the guardians of the socio-political transformation project? The answer to this question is likely to be highly contested given that the concept challenges the traditional position in common law jurisdictions that

107 JB Ojwang Ascendant judiciary in East Africa: Reconfiguring the balance of power in a democratising constitutional order (2013).

108 J Ferejohn 'Judicialising politics, politicising law' (2002) 65 Law and Contemporary Problems 41.

109 A Bickel The least dangerous branch: The Supreme Court at the bar of politics (1962).

110 AS Sweet Governing with judges: Constitutional politics in Europe (2000).

111 Klug (n 58 above).

112 Ojwang (n 107 above).

113 As above. 
judges must always exercise restraint as they are not law makers. ${ }^{114}$ As noted above, judicialism is at the core of transformative constitutionalism since the concept places faith in the law as an instrument of social and political change, and in the courts as the 'midwives' of the transformation since courts are legally mandated to interpret and apply the law. To succeed in this position of trust, it follows first and foremost that the judiciary must assume a more assertive position than in ordinary traditional contexts. This was acknowledged by the High Court of Kenya in Trusted Society of Human Rights Alliance $v$ Attorney-General \& 2 Others, ${ }^{115}$ in which the Court described itself as a 'co-ordinate' and 'co-equal' arm of government with the mandate to interfere with the decisions of the political arms which offend or exceed the limits of the Constitution and the law generally. ${ }^{116}$ In other words, courts can no longer view themselves as subordinate to the other arms in the scheme of government. ${ }^{117}$ This, by extension, requires courts to liberate themselves from previously self-imposed restraints that undermined their position in the equilibrium of governmental power. ${ }^{118}$ These restraints include legal culture, particularly how judges and lawyers appreciate the spirit of the Constitution and its purposes. In addition, it also entails how judges perceive their role to be in a democracy. As Klare notes, legal culture affects how lawyers and judges see the law and relate it to politics and society. ${ }^{119}$ Thus, a failure by judges to appreciate the breadth of their role and that of the law could undermine transformative aspirations of the Constitution. ${ }^{120}$ In the context of transformative constitutionalism, judges must commit to doing more with the law. They must be aware of the prominence that they enjoy and society's expectations of the courts. In Communications Commission of Kenya \& 5 Others $v$ Royal Media Services Limited \& 5 Others, ${ }^{121}$ the Supreme Court of Kenya recognised that '[t]he judiciary

114 Langa (n 85 above) 351, contending that there is no single accepted and stable definition for transformative constitutionalism as the word 'transformation by itself has changeable features'. See also D Moseneke 'The fourth Brian Fischer Memorial Lecture: Transformative adjudication' (2002) 18 South African Journal on Human Rights 315 , stating that 'the meaning of transformation in juridicial terms is as highly contested as it is difficult to formulate'.

115 [2012] eKLR.

116 As above.

117 In Kenya's history, eg, there was a time when the judiciary was seen as a 'third $\mathrm{arm}^{\prime}$ of government subservient to the political arms. See eg Mutua (n 34 above).

118 SB Pfeiffer 'The role of the judiciary in the constitutional systems of East Africa' (1978) 16 Journal of Modern African Studies 33.

119 As above.

120 Mwaura \& 2 Others $v$ Republic (Criminal Appeal 5 of 2008) issued in October 2013, where the Court of Appeal in Kenya refused to outlaw the death penalty arguing, among other things, that the power to do so lies with the legislature. This is to be contrasted with the decision of the South African Constitutional Court Africa in $S \vee$ Makwanyane in which the court invalidated the death penalty. The material facts in the two cases are similar.

121 [2014] eKLR (Petition 14 as Consolidated with Petitions 14A, 14B and 14C of 2014). 
has been granted a pivotal role in midwifing transformative constitutionalism and the new rule of law in Kenya'. ${ }^{122}$ While the text of the Constitution is the vehicle for political, economic and egalitarian social transformation, the judiciary enjoys the powerful and influential position of being the driver of this vehicle. Thus, the potential of change through the Constitution cannot amount to much unless the courts live up to the task in the adjudication of rights and their enforcement in real cases. ${ }^{123}$ This decision is also significant in that the highest court in Kenya formally recognised transformative constitutionalism as the ideology that undergirds the country's 'new' constitutional dispensation. In other words, the Constitution in its design and vision is transformative, and the courts have the duty to implement transformative constitutionalism. ${ }^{124}$

Klare contends that the judicial mindset founded on a particular legal culture must be 'examined and revised so as to reflect the transformative conception of adjudicative process and method envisaged by the doctrine of transformative constitutionalism'. ${ }^{125}$ The High Court of Kenya in The Very Right Rev Dr Jesse Kamau \& Others $v$ The Hon Attorney-General \& Another, quoting the former Chief Justice of The Gambia, EO Ayoola, observed that a 'timorous and unimaginative exercise of the judicial power of constitutional interpretation leaves the Constitution a stale and sterile document' ${ }^{126}$ On interpretation of rights in particular, the Court went on to note: ${ }^{127}$

The provisions touching fundamental rights have to be interpreted in a broad and liberal manner, thereby jealously protecting and developing the dimensions of those rights and ensuring that our people enjoy their rights, our young democracy not only functions but also grows, and the will and dominant aspirations of the people prevail. Restrictions on fundamental rights must be strictly construed.

This implies that rights and duties established by substantive postliberal alterations to constitutional foundations cannot be interpreted according to, and therefore constrained by, past intellectual instincts and judicial mindset. ${ }^{128}$ As noted above, an approach that transcends legal formalism and positivism is necessary. Additionally, Mureinik

122 As above.

123 For a similar argument in relation to the South African context, see E Christiansen 'Transformative constitutionalism in South Africa: Creative uses of Constitutional Court authority to advance substantive justice' (2010) 13 Journal of Gender, Race and Justice 575.

124 W Mutunga 'The 2010 Constitution of Kenya and its interpretation: Reflections from Supreme Court decisions' Inaugural Lecture Series, University of Fort Hare, 16 October 2014, http://www.judiciary.go.ke/portal/assets/files/Lectures/CJ\%20 LECTURE\%20AT\%20FORT\%20HARE\%20UNIVERSITY\%20LECTURE,\%20SA.pdf (in which the Chief Justice of Kenya (as he then was) remarked that the courts had the obligation under the Constitution to implement transformative constitutionalism).

125 Klare (n 51 above) 156.

126 Nairobi HCMCA 890 of 2004 (unreported).

127 As above.

128 Klare (n 51 above) 156. 
suggests that 'an opening to transformation requires the changing of legal culture from a culture of authority to culture of justification', ${ }^{129}$ Consequently, under a transformative constitution, judges must as of necessity justify their decisions not only by reference to precedence and other legal authority, but by reference to certain overarching principles and values. ${ }^{130}$ Similarly, any attempts by the legislature to restrict fundamental rights and freedoms must be strictly justified. The power to assess any measure restricting rights to determine whether it meets constitutional standards is vested in the judiciary. This is the essence of proportionality balancing discussed below.

The points noted above raise the question of the place of judicial deference to the political arms of government and the doctrine of separation of powers. To be clear, transformative constitutionalism does not dispense with judicial deference. Rather, as of necessity, it abhors hasty deference. It demands a deeper engagement to discover the deep meaning of values and the socio-political aims of the Constitution and a readiness to strike so as to safeguard them. This was noted by the High Court of Kenya in Trusted Society of Human Rights Alliance $v$ Attorney-General \& 2 Others, ${ }^{131}$ where the Court emphasised that a review of the decisions of the political arms of government that do not meet constitutional standards does not violate the principle of separation of powers. Rather, the Court held, it is an incidence of separation of powers since the courts are the guardians of the meaning of the law. Relatedly, courts must reject undue attention to technicalities and a cursory approach to adjudication since, as noted above, substantive justice and real enjoyment of rights are the ultimate objectives of transformative constitutionalism. 132 As Brand has remarked, judicial deference becomes pernicious when it 'operates as an obstacle to effective judicial enforcement of rights'. ${ }^{133}$ This argument is best captured in the Kenyan context by Musila when he notes that 'the judiciary must understand and appreciate the true nature of our Constitution and the multiple paradigm shifts it introduces'. ${ }^{134}$ As part of the package, courts can no longer take shelter in the concept of 'judicial restraint $^{\prime}, 135$ or the age-old idea that common law judges do not

129 Mureinik (n 73 above) 33.

130 Langa (n 85 above) 353.

131 [2012] eKLR.

132 Klare (n 51 above). This requirement not to give undue attention to technicalities is enshrined in arts 22(3)(b) \& (d) and 159(2)(e) of the Kenyan Constitution. However, it is important to note that procedural technicalities in criminal proceedings are intended to, and usually have the effect of, protecting the rights of the accused person.

133 D Brand 'Judicial deference and democracy in socio-economic rights cases in South Africa' (2011) 22 Stellenbosch Law Review 637.

134 GM Musila 'Realising the transformative promise of the 2010 Constitution and new electoral laws' in GM Musila (ed) Handbook on election disputes in Kenya: Context, legal framework, institutions and jurisprudence (2013) 3.

135 As above. 
make law. ${ }^{136}$ Under the constitutional scheme judges, in addition to their traditional roles and powers, are also vested with the task of 'developing' the law. To put it differently, the judge is not merely a midwife; she is also a surgeon with the power to clip existing law to bring it in conformity with the aspirations of the Constitution. Discourses on transformative constitutionalism suggest that the change in the judicial attitude and approach advocated by the concept is beyond the traditional role of judges in Kenya and most other commonwealth common law jurisdictions. However, the contours of this enhanced judicial power and how it relates to the powers of other arms of government may be hard to define. Nonetheless, this power is constitutionally mandated, and a failure to exercise it the adjudication of human rights and constitutional issues generally is tantamount to an abdication of judicial duty contrary to the oath of office.

Another demand of transformative constitutionalism on the judge is what Klare describes as a 'historical self-conscious doctrine ${ }^{137}$ in adjudication. This means that it pays regard to the 'legal history, traditions and usages of the country concerned'. ${ }^{138}$ It essentially recognises the injustices of the past and seeks to remedy them, thereby avoiding their repetition. The significance of this historical consciousness was effectively captured in the words of Chaskalson P in the South African Constitutional Court decision in $S v$ Makwanyane \& Another, ${ }^{139}$ when he noted that while construing the Constitution, due regard must be paid to the legal system and also the history of the country. ${ }^{140}$ The outcome of this approach was the invalidation of the death penalty in South Africa, first as a step of dismantling an instrument that had helped to advance the apartheid agenda and, second, in recognition of human dignity and human rights for all including those the majority would not favour, such as criminal convicts. ${ }^{141}$ The Kenyan Supreme Court has also recognised the value of history in constitutional interpretation. In Speaker of the Senate \& Another $v$ Attorney-General \& 4 Others, ${ }^{142}$ Chief Justice Mutunga (now retired) in his concurring opinion observed that the Supreme Court $\mathrm{Act}^{143}$ 'allows the Court to explore interpretive space in the country's

136 SB Sinha 'Creative interpretation of the Constitution: Role of the Supreme Court of India' (2004) Delhi Judicial Academy Journal 26.

137 Klare (n 51 above) 155.

138 S v Zuma 1995 (2) SA 642 (CC) para 15, per Kentridge J.

139 Makwanyane (n 98 above).

140 Makwanyane para 39, per Chaskalson P.

141 E Kibet 'Death penalty in Kenya: A call for conformity with international human rights law and the Constitution' (2011) 7 Law Society of Kenya Journal (on file with authors).

142 Advisory Opinion Reference 2 of 2013; [2013] eKLR.

143 Sec 3 of the Supreme Court Act provides that ' $[\mathrm{t}]$ he object of this Act is to make further provision with respect to the operation of the Supreme Court as a court of final authority to, among other things ... (c) develop rich jurisprudence that respects Kenya's history and traditions and facilitates its social, economic and political 
history and memory ... even beyond the minds of the framers ...' In other words, the struggles and hopes contained in history are a rich source of guidance in interpretation if the transformative ambitions are to be realised. This is because the socio-political situation of a country is often a product of its history. De Vos, however, cautions that the application of history as a guide in constitutional interpretation is a slippery path, especially if taken as a 'grand narrative'. ${ }^{144}$ This, he argues, is because history is a 'profoundly subjective account of selected events in the past'. ${ }^{145}$ To mitigate the dangers posed by this character of history, he suggests that history should be applied with an 'acknowledgment of its "open-ended" nature'. 146

This far, it is clear that transformative constitutionalism is an 'activist' philosophy aimed at social and political emancipation through legally-mandated means. Inevitably, this calls for an 'activist' approach in the adjudication of rights. ${ }^{147}$ To this effect, Rapatsa notes that since the doctrine 'envisages achieving legal and social change in broader terms', the 'adjudication process ought to explicitly adapt to an activist transformative approach'. ${ }^{148}$ As already noted, the objective is substantive justice and substantive equality. This necessarily means that quite often the courts will have to scrutinise situations of hidden discrimination and take positions that advance equality even if such positions will go against prevailing social attitudes and prejudices. The decisions of the South African Constitutional Court cited above, such as invalidating the death penalty; striking down laws criminalising sex between consenting males; validating same-sex marriages; and affirming the right of a lesbian couple in a permanent relationship to jointly adopt a child; illustrate this point. As a matter of fact, these decisions and others have distinguished South Africa's jurisprudence in Africa and globally. ${ }^{149}$

Transformative constitutionalism aims to engender what the Constitutional Court of South Africa refers to as a 'culture of rights' ${ }^{150}$ This, as Langa explained, entails upholding '[a] culture of respect for

growth; (d) enable important constitutional and other legal matters, including matters relating to the transition from the former to the present constitutional dispensation, to be determined having due regard to the circumstances, history and cultures of the people of Kenya' (our emphasis).

$144 \mathrm{P}$ de Vos 'A bridge too far? History as context in the interpreting the South African Constitution' (2001) 17 South African Journal on Human Rights 1.

145 As above.

146 As above.

147 Fombad (n 50 above) 1069.

148 M Rapatsa 'Transformative constitutionalism in South Africa: Twenty years of democracy' (2014) 5 Mediterranean Journal of Social Sciences 889.

149 DB Maldonado 'Constitutionalism of the global south: The activist tribunals of India, South Africa and Colombia (2004). Eg, South Africa is among a few countries in the world that allow same-sex marriages and have completely abolished the death penalty.

150 Makwanyane (n 98 above) 222 (Langa J concurring). 
human life and dignity, based on the values reflected in the Constitution'. 151 The doctrine builds on the 'constitutional conception of democracy', recognising that 'democracy is not simply majoritarianism, since it constrains majority decision making consistently with the protection of rights'. ${ }^{152}$ Therefore, the logic of 'engendering a culture of rights' demands a 'radical', meaningful and effective approach to the protection of rights. It demands individual rights and freedoms to be taken seriously and, therefore, 'when judges decide whether a limitation of a right is constitutional, they should not accept the decision maker's word for it, but should decide the question for themselves'. ${ }^{153}$ Transformative constitutionalism mandates a principle of strict scrutiny where a constitutional right is alleged to have been breached. To achieve this, both the Kenyan and South African Constitutions have incorporated proportionality balancing as a tool for ensuring that rights are given effect to and are safeguarded from unjustified restriction, especially where the state has competing countering values or interests to uphold, such as national security, public morality, public safety, public order or the rights of others. $^{154}$ The criteria seek to maximise the protection of rights by constraining limitations in an objective fashion to allow only restrictions that pass strict scrutiny under the clause.

Pulido and other scholars see proportionality balancing as 'one of the most successful legal transplants' and a key feature of global constitutionalism. ${ }^{155}$ With roots in German administrative law, the concept has found acceptance across Europe, Australia, New Zealand, Canada and South Africa. ${ }^{156}$ The concept has most recently become entrenched in Kenya's human rights adjudication. ${ }^{157}$ The test demands that restrictions of fundamental rights be 'reasonable and justifiable in an open and democratic society'. ${ }^{158}$ The test is set in motion the moment it is established prima facie that a law in question interferes with a fundamental right. It is important to note that, to be legitimate, any purported limitation of rights must be grounded in

151 Makwanyane (n 98 above).

152 A Kaufman 'Rights and disagreement' (2013) 3 Philosophy Study 229.

153 P Lenta 'Judicial deference and rights' (2006) Journal of South African Law 456463.

154 Art 24 Constitution of Kenya; sec 36 Constitution of South Africa.

155 CB Pulido 'The migration of proportionality across Europe' (2013) 11 New Zealand Journal of Public and International Law 483. The terms 'proportionality' or 'proportionality balancing' are not found in the instruments that incorporate limitation clauses. These were developed by the courts and scholarly literature to describe the test set under the limitation clauses.

156 AS Sweet \& J Matthews 'Proportionality balancing and global constitutionalism' (2008) 47 Columbia Journal of Transitional Law 81. It has also found acceptance beyond public law, where it was first applied, to other areas of law, and in international tribunals such as the European Court of Justice, the European Court of Human Rights and the dispute settlement mechanism of the World Trade Organisation. For South Africa, see sec 36 of the Constitution of South Africa 1996.

157 See art 24 of the Constitution of Kenya and its application by the High Court of Kenya in the CORD case (n 103 above).

158 As above. 
law, consistent with the idea of the rule of law as a mechanism to check arbitrariness. Although there are variations in the elements of the proportionality test, its most comprehensive version consists of four components. ${ }^{159}$ The first component is the legitimacy of the objective that the state seeks to achieve through the limitation. 160 This means that the grounds for limitation are not open-ended. ${ }^{161}$ The judge has to confirm that the state interest or countervailing value is constitutionally legitimate. ${ }^{162}$ Legitimate goals include national security, public safety, public morality, and the rights and reputation of others. ${ }^{163}$ The second step is an assessment of the suitability of the measure taken. ${ }^{164}$ Under this component, the critical question is whether the step or measure taken is rationally connected to the stated objective. ${ }^{165}$ There has to be a rational connection between the measures taken or sought to be taken with the overall objective. $^{166}$ The third is necessity. ${ }^{167}$ Under this component, the assessment focuses on whether the government has imposed a greater restriction than is necessary to achieve the objective. The rule is that the least restrictive method must be preferred in the course of limiting rights. ${ }^{168}$ As it is often put figuratively, 'one does not need a sledge hammer if a nutcracker can do the job'. ${ }^{169}$ If a measure taken or proposed by the state does not pass these three tests, the outcome is that it is unconstitutional and therefore invalid. ${ }^{170}$ However, if a restriction to a right passes the three tests, the inquiry proceeds to the next step. The fourth step is balancing in the strict sense or proportionality in the narrow sense. ${ }^{171}$ The assessment here takes the form of a cost-benefit analysis. The government measure that is already found to be narrowly tailored and has passed the first three tests is subjected to a balancing. This balancing assesses the cost of the restriction measured against the competing right or the countervailing state interest or value. ${ }^{172}$ This step weighs the anticipated benefit arising from the restriction against the weight of

159 Sweet \& Matthews (n 156 above).

160 As above).

161 As above.

162 F Urbina 'A critique of proportionality' (2012) 57 American Journal of Jurisprudence 49.

163 As above.

164 As above.

165 As above.

166 As above.

167 As above.

168 As above.

169 As above.

170 As above.

171 As above.

172 As above. 
the right that is sought to be limited to determine what is more constitutionally valuable and what should be upheld. ${ }^{173}$

The upshot of this test is that rights are important and must be taken seriously. Therefore, the political arms of the state may not arbitrarily limit them. Any attempts to do so will be thwarted by the courts in exercise of their judicial mandate. This approach has been criticised for failure to appreciate the principle of separation of powers to the extent that judges do not 'show appropriate deference to the judgments of the elected branches and administrative agencies'.174 This criticism can be countered by the fact that in constitutional democracies, rights cannot be left entirely to the majoritarian wishes of either the people or their elected representatives. In other words, the essence of the Bill of Rights is to remove certain constitutional matters from the reach of the majoritarian premise. As Lenta points out, 'if the court thinks that the rights of individuals are being infringed and that the infringement is not justified by a sufficiently important competing public interest', the doctrine of transformative constitutionalism demands that the court should not defer. ${ }^{175}$ Instead, it must take a stand to defend fundamental rights. While this appears to be inconsistent with democratic majoritarian premise, its justification is found within the Constitution itself. In other words, the realisation of transformative constitutionalism is a product of the judicial approach and enabling substantive constitutional provisions.

As already noted, Klare's idea of transformative constitutionalism is multi-faceted. It entails constitutional enactment and the design of the Constitution, as well as its interpretation, and enforcement. In this sense, substantive constitutional provisions in transformative constitutions such as those of Kenya and South Africa on interpretation of rights, elaborate bills of rights with limitation clauses to safeguard rights, and so forth, form the core of the idea of transformative constitutionalism. Similarly, judicial approaches in the interpretation and enforcement of the substantive provisions in a way that results in the highest realisation of rights and substantive justice are pivotal components of transformative constitutionalism.

In the final analysis, it is clear that despite some challenges, the transformative designs of the South African and Kenyan Constitutions have yielded better prospects for constitutionalism and the protection of fundamental rights. As noted above, the prospects of the rule of law, constitutionalism and the protection of rights in Kenya are better than at any other time in the country's history. The same may be said

173 As above. This cost-benefit inquiry is very political in nature as it seeks to reconcile competing political interests. The process is an analysis of policy considerations that is typical of the legislative process.

174 See, eg, C Hoexter 'The future of judicial review in South African administrative law' (2000) 117 South African Law Journal 484. See also K O'Regan 'Breaking ground: Some thoughts on the seismic shift in our administrative law' (2004) 121 South African Law Journal 424.

175 Lenta (n 153 above) 463. 
of post-apartheid South Africa. Many countries in Africa continue to wobble in the path of democracy, constitutionalism, the rule of law and the protection of human rights. Obvious examples in this regard are Zimbabwe, Burundi, Rwanda, the Democratic Republic of the Congo (DRC) and Uganda, where incumbent presidents have insisted on hanging on to power either in violation of the Constitution or through political manipulation of the Constitution to validate their stay. Others, such as Central African Republic, Libya, South Sudan and Somalia, are embroiled in war and a breakdown of constitutional order. Yet others, such as Zambia and Tanzania, although peaceful, have recently undergone political transition and are in the process of reviewing their Constitutions. These facts indicate that many countries in Africa are currently in or will soon be in a watershed moment for constitutional reform since the conclusion of the situations they currently face are likely to be mediated through constitutional change. While constitutions are domestic instruments reflecting and catering for local situations, ${ }^{176}$ it is also a fact that modern constitutions are anything but sui generis. ${ }^{177}$ Thus, the transformative Constitutions of Kenya and South Africa provide good models that could be tailormade to fit the peculiar situations of these countries.

\section{Conclusion}

The article explores the concept of transformative constitutionalism in the context of Kenya and South Africa. Popularised in the South African context by Klare and other scholars, the article notes that the concept is the central ideology undergirding the Constitutions of the two countries. Using examples of cases from superior courts of record from the two jurisdictions, the article argues that transformative constitutionalism has resulted in better judicial adjudication and protection of fundamental rights and freedoms and yielded better prospects for democracy, constitutionalism and the rule of law. Therefore, the article concludes that transformative constitutionalism and the Constitutions of Kenya and South Africa provide good models that may be tailor-made to anchor these values in Africa, especially for those countries that are currently undergoing or will soon be undergoing constitutional and political reforms.

The article discussed past failures of constitutionalism and human rights abuses in post-colonial Africa, and noted that amidst the crises, courts were either complicit or too weak to stand up to the political arms of government. The article summarised the features of transformative constitutionalism generally and analysed its demands on judges and the adjudication of fundamental rights and freedoms. Transformative constitutionalism, simply put, aims at achieving social

$176 \operatorname{Klug}$ (n 58 above)

177 Klug 6-7 (arguing that constitutions in modern times are becoming more and more similar in core concepts). 
and political transformation through the law. It focuses on attaining substantive justice and substantive equality and entrenching egalitarianism in social and political relationships generally. To achieve this, transformative constitutionalism embraces judicialism, giving the law and, by extension, the courts a prominent place in the transformation process. This requires a judicial consciousness of the historical background that informs the present social and political situations it seeks to redress. In addition, it necessarily demands less insistence on legal and procedural technicalities that quite often defeat the enforcement of substantive rights and duties under the law.

It is clear that in the context of transformative constitutionalism, the judiciary enjoys a pivotal position given the prominence of the law and its constitutional mandate to interpret and enforce fundamental rights. Given this prominence, the article argues, judges in the context of transformative constitutionalism must be prepared to do more with the law in order to realise its purposes. This includes a psychological shift to appreciate the high expectations placed upon their shoulders and assume a more confident position in the scheme of government. This necessarily requires the pursuit of 'rights-friendly jurisprudence', or a philosophy that favours the enjoyment of fundamental rights, and a preparedness to reject judicial deference to political arms where the law and the Constitution are violated or threatened with violation. The contours of this 'new' judicial attitude that transformative constitutionalism requires is bound to be difficult to define. However, this is an inevitable shift that must be made, and is likely to preoccupy judges and commentators for a long time to come. 